\title{
Social Innovations as Drivers of Social Change - Exploring Tarde's Contribution to Social Innovation Theory Building
}

Jürgen Howaldt, Ralf Kopp and Michael Schwarz

\section{Introduction}

In the context of seemingly intractable social challenges such as climate change, environmental destruction, youth unemployment and social exclusion, social innovation has emerged as a potentially sustainable solution. It is often assumed that social innovation can lead to social change (see, for example, Cooperrider and Pasmore, 1991; Mulgan et al., 2007; BEPA, 2010). However, the relationship between social innovation and social change remains underexplored:

Rather than being used as a specifically defined specialist term with its own definable area of studies, social innovation is used more as a kind of descriptive metaphor in the context of phenomena of real world problems, social change, and the modernisation of society. (Howaldt and Schwarz, 2010, p. 49)

There is still no consistent or coherent concept of social innovation grounded in social theory that is suitable for empirical research (Mulgan, 2012; European Commission, 2013, p. 26). The result is 'an incoherent body of knowledge on social innovation with the consequence that there is a lack of clarity of the concept of social innovation' (Rüede and Lurtz, 2012, p. 2). The scientific discussion on social innovation is polarised between an actor-centred, individualistic, attitude-orientated perspective on the one hand and an implicit, structuralist perspective on the other. Social innovations are either attributed to individualistic acts or considered as deterministic results of external context (CajaibaSantana, 2014; European Commission, 2013). Given the fact that social theory does not yet play an important role in social innovation research 
(Howaldt and Schwarz, 2010; Mulgan, 2012; Moulaert et al., 2013; European Commission, 2013), its possible contributions are worthy of exploration.

In light of the increasing importance of social innovation, this chapter focuses on a conception of social innovation that is grounded in social theory, as a precondition for the development of an integrated theory of socio-technological innovation in which social innovation is more than a mere appendage, side-effect and result of technical innovation. Against this background, social innovation is defined here as a new combination ${ }^{1}$ or configuration of practices in areas of social action, prompted by certain actors or constellations of actors with the ultimate goal of coping better with needs and problems than is possible by using existing practices (Howaldt and Schwarz, 2010, p. 54). An innovation is, therefore, 'social' to the extent that it varies social action and is socially accepted and diffused in society (be it throughout society, through large parts of it or only in certain societal sub-areas). Depending on the circumstances of social change, interests, policies and power, social ideas and successfully implemented social innovations may be transformed and, ultimately, institutionalised as regular social practice, that is, made routine. From this perspective, social innovations can be seen as actions that spread through society as a result of imitation, bringing about social change: a 'process of change in the social structure of a society in its constitutive institutions, cultural patterns, associated social actions and conscious awareness' (Zapf, 2003, p. 427). Only by taking into account the unique properties and specifications of social innovation will it be possible to understand the systemic connection and interdependence of social and technological innovation processes to analyse the relationship between social innovation and social change.

This chapter aims to outline how Gabriel Tarde's social theory can be of benefit in developing a theoretically grounded concept of social innovation and how it can be reinterpreted in terms of practice theory. ${ }^{2}$ In comparison with action, system and structural theories, this perspective on social innovation is based upon a modified understanding of the 'social' as social practices and their reconfiguration as a core element of social innovation (Shove et al., 2012). Practice theories overcome the dichotomies between structure and action, subject and object, rule and application, society and the individual, that arbitrarily define micro and macro levels or sociological 'reality rules' (Latour and Lépinay, 2010, p. 114). Tarde focuses on social practices as the central theoretical and analytical category and last unit of sociality. The social world is, therefore, composed of specific, although interdependent practices: practices of 
governance; practices of organising; practices of partnership; practices of negotiations; practices of self (Reckwitz, 2003); practices of comfort, cleanliness and convenience (Shove, 2003); practices of working and nurturing (Hargraves et al., 2011) and practices of consumption (Brand, 2011; Warde, 2005).

By defining social innovation 'as a new combination or configuration of practices', an approach can be found in recent social theory that focuses on the social practices and dynamics of change. In the conclusion of their paper analysing definitions of social innovation from various disciplines, Rüede and Lurtz (2012) recognised the potential for future research in practice theory. As part of the 'practice turn' in the field of social sciences (Schatzki et al., 2001; Reckwitz, 2003), practice theories - for example those of Bourdieu, Giddens and Latour - can be seen as important components of a theory of social innovation (Howaldt and Schwarz, 2010), essential for analysing 'the dynamics of social practice' (Shove et al., 2012). In this sense, social innovation can be:

Interpreted as a process of collective creation in which the members of a certain collective unit learn, invent and lay out new rules for the social game of collaboration and of conflict or, in a word, a new social practice, and in this process they acquire the necessary cognitive, rational and organizational skills. (Crozier and Friedberg, 1993, p. 19) [emphasis added]

Social innovation encompasses new practices (concepts, policy instruments, new forms of cooperation and organisation), methods, processes and regulations that are developed and/or adopted by citizens, customers and politicians, in order to meet social demands and to resolve societal challenges in a better way than existing practices.

This chapter starts with a short review of Ogburn's concept of social change, which laid the foundation for a specialised sociology of change. Ogburn's concept provided important input into a better understanding of technological and social innovation on the one hand and social change on the other. However, it is only through recourse to the social theory of Tarde that the opportunities arising from a sociology of innovation for the analysis of social change become apparent. This is the subject of the following section. For Tarde, social macrophenomena such as social structures, systems and social change are 'easy to describe, but hard to explain, because the true complexity resides in the microphenomena' (Gilgenmann, 2010, p. 2). His basic idea was to explain social change from a 'post-foundationalism' (Marchart, 2013) perspective and 
not objectivistically (like Durkheim) from the top down, in terms of social facts and structures (Gilgenmann, 2010, p. 7), or subjectivistically, following the approaches of social phenomenology, symbolic interaction or ethno-methodology (Marchart, 2013, p. 45). Recourse to Tarde helps to overcome the restriction of the concept of innovation to purely economic aspects. Taking his micro sociological approach as a starting point, key implications are outlined in the final section of this chapter. This analysis allows a theoretically grounded understanding of social innovation on which innovation policy can be built.

\section{Theoretical foundations for social innovation}

Theories of social change have been at the core of sociology since its beginning. So far, however, no consistent theory has emerged. In particular, theory has difficulties with social change that is not continuous and linear (Weymann, 1998, p. 17). In so far as sociological theories deal with processes of change, they do so almost universally from the perspective of the reproduction, and not the transformation of social order. Social change in the sense of fundamental transformations at the macro (structural) level - that function as 'mega trends' or as a sequence of phases separated by (epochal) upheavals - belongs to the field of the sociological diagnosis of epochs. This can manage completely without social theory and the same time is often mistaken for it (Osrecki, 2011).

Social innovation, as an analytical category, has remained, at best, a secondary topic in both classical and modern social theory - often in relation to concepts such as social differentiation and social integration, social order and social development, modernisation and transformation. The social sciences refuse to a large extent to 'present and list as social innovations the relevant social changes' that they have discovered and studied (Rammert, 2010, p. 26). ${ }^{3}$

Ogburn theorised the basis for a comprehensive theory of innovation. Ogburn made 'cultural lag' - the difference in the time it takes for the comparatively slow, non-material culture to catch up with the faster developing material culture - his analytical starting point. He systematically differentiated between technological and social innovations (and inventions) as critical factors in social change. He also explained that the use of the term 'inventions' is not restricted to the technological but can also be used to include 'social inventions', such as the League of Nations:

Invention is defined as a combination of existing and known elements of culture, material and/or non-material, or a modification of 
one to form a new one. [...] By inventions we do not mean only the basic or important inventions, but the minor ones and the improvements. Inventions, then, are the evidence on which we base our observations of social evolution. (Ogburn, 1969, p. 56 ff.)

Thus, Ogburn was convinced that in the interplay between invention, accumulation, exchange and adaptation, he had discovered the basic elements of 'cultural development' and hence - like Darwin for biological evolution - had developed a model to explain social evolution.

Although Ogburn's approach allowed for the analysis of social innovations as drivers of social change, the debate in the field of the sociology of technology concerning the relationship between technological and social innovation and social change has tended to conceptualise the former as independent from technological development. ${ }^{4}$ Ogburn started by exploring the interrelationship between the 'material' and 'non-material elements of culture'. He assigned to 'innovations in the non-material field' the character of 'secondary changes' in the sense of an 'adaptation to a change in the material field' (Ogburn, 1969). This was further conceptualised as an 'invention in the field of technology or a discovery in applied science' that can have an extraordinarily large effect 'with great likelihood in changes in other cultural fields' or even in the 'formation of completely new social institutions' (ibid., p. 67). In this original interpretation, social change was understood as a process of the diffusion of innovations and, hence, as the imitation or adoption of a (technological or social) invention by others - sometimes as an emergent innovation process in which social innovations are primarily ascribed the function of a (delayed) adaptation in the sense of a 'cultural lag' (Ogburn, 1969, p. 64).

At the same time, it is overlooked that in his later work, Ogburn referred to an important misunderstanding of his concept. In an essay published in 1957, he wrote:

In most of the examples I gave at that time, the starting point was a technological change or a scientific discovery, and the lagging, adaptive cultural element generally was a social organisation or an ideology. These examples led some researchers to think the cultural lag theory was a technological interpretation of history. Yet when the cultural lag theory was published, I pointed out that the independent variable could just as well be an ideology or other non-technological variable [...]. So the fact that the technological changes always came first was simply due to the fact that at a particular point in time, only 
certain observations were available; but it is not an inherent part of the theory (Ogburn, 1969, p. 139). ${ }^{5}$

Yet, these aspects of Ogburn's theory - that could have formed the basis for a comprehensive theory of innovation - remained largely ignored in a wider theoretical context in which there was a one-sided focus on the relevance of technology for social change (Freeman, 1974; OECD, 1997).

Only in recent years has a new understanding of the innovation process become more important, in which openness towards society is central (FORA, 2010, p. 15 ff.). Individual aspects of this development are reflected in terms and concepts such as 'open innovation', 'customer and user integration', '(innovation) networks', 'multi-stakeholder dialogues' and 'the new power of the citizenry' (Marg et al., 2013). The development of 'robust design concepts' (Gross et al., 2005) and institutions that combine research and innovation with 'post-conventional forms of participation' (Marg et al., 2013, p. 8) are explicitly the subject matter of, for example, transition management, transdisciplinary sustainability research, governance research and, particularly, network research (for example, Powell and Grodal, 2005). Thus, at the same time, social innovation has started to be seen as a type of innovation that is distinguishable from technological innovation with its own subject area, sphere of influence and field of application (Howaldt and Schwarz, 2010).

However, it is not possible to define social innovations solely by referring to a distinct social sphere or to socially desirable outcomes as their key purpose (Rammert, 2010, p. 40). Rather, what is at issue is the substantive core of the innovation. With social innovations, the new does not manifest itself in the medium of technological artefacts, but at the level of social practices. If it is accepted that the invention and diffusion of the steam engine, the computer or the smartphone should be regarded differently from the invention and social spread of a national system of healthcare provision, the concept of corporate social responsibility (CSR) or a system of micro lending, then it stands to reason that there is an intrinsic difference between technological and social innovations. While it is true that all innovations, regardless of their object, can be viewed as a social phenomenon, this does not obviate the need empirically to research the commonalities and differences between these two types of innovation. Even if, in reality, both types closely connect with each other in socio-technological systems, the need for analytical distinction does not disappear. This is all the more urgent given that existing sociological innovation research, that has emanated 
mainly from the sociology of technology, centres on the investigation of technological innovations:

If one asks what are the relevant innovations of the last 100 years or if one reads lists of the most important innovations, the answer usually is a series of technological inventions. (Rammert, 2010, p. 25) ${ }^{6}$

From this perspective, it becomes more important to devote greater attention to social innovation as a mechanism of change residing at the micro and meso levels. There are two main reasons for this. First, the shortcomings of older models of social change - and of an economically and technologically focused innovation model - have become increasingly apparent when dealing with the key social challenges (Howaldt and Schwarz, 2010). Second, new forms of social self-management, of the 'criticism that actually takes place in society' (Vobruba, 2013, p. 160), are becoming increasingly evident.

In the context of broader debates about sustainable development, there is a question about the relationship between social innovation and the transformative change of existing structures, policies, institutions and behaviours that aim to improve the quality of life. How can processes of transformative social change (Moore and Westley, 2011) be initiated which link social innovations from the mainstream of society with the intended social transformation processes? This

refers to moving an innovation into a broader system and creating transformation through the linking of opportunities and resources across scales. Quite often, to effect transformative change in a broader system, the innovation will be reconfigured into an entirely new form to suit that context. (Moore and Westley, 2011)

\section{Tarde's analysis of social change}

Recourse to Tarde may be helpful in gaining a better theoretical understanding of the relationship between social innovation and social change (Howaldt et al., 2014). Instead of explaining social change objectivistically or subjectivistically, he argued in terms of social practices of invention and imitation. Tarde's contribution to the understanding of a sociology of innovation can be used for developing a concept of social innovation as a social mechanism of change residing at the micro and meso levels. This seems all the more necessary given that Tarde's social 
theory - in terms of its implications and usefulness in the analysis of innovation - has been little explored until now. ${ }^{7}$

Revisiting Tarde's social theory - which, at its core, is a sociology of innovation - allows a widening of perspective on the nature of social innovation. This goes beyond the economic and technological innovations noted by Schumpeter (1964) and, after him, by the sociology of technology focused either on the social consequences of technology (Ogburn, 1937) or on the 'social shaping of technology' (MacKenzie and Wajcman, 1985; Williams and Sörensen, 2002) or 'social construction of technological systems' (Bijker, Hughes and Pinch, 1987). At the same time, this new focus reveals the blind spots of a narrow economic view. Because Tarde places the laws of the practices of imitation at the centre of his theory of social development, the associated micro foundations of social phenomena provide vital input into an integrative theory of innovation. It enables a discovery of how social phenomena - conditions and constructs - come into being and how they change. The key to this discovery is to analyse the development of social inventions and innovations as well as the associated social practices of their imitation.

Unlike Schumpeter, for whom the innovator - namely the 'entrepreneur' is the focus of interest, Tarde is concerned with the inventions that are understood to be the central driver of social change. For Tarde, these are the many small inventions and ideas,

which were difficult or easy to arrive at and mostly went unnoticed at the time of their arising, which therefore are usually almost exclusively inglorious and nameless. (Tarde, 2009b, p. 26)

These countless inventions can change society and its practices through multiple acts of imitation, and only as a result of imitation do these inventions become an innovation and a true social phenomenon: 'In the realm of the social, everything takes place as invention and imitation, with imitation forming the rivers and inventions the mountains' (ibid, p. 27). For Tarde, imitation is the central mechanism of social reproduction and of social change:

All similarities of social origin that belong to the social world are the fruits of some kind of imitation, be it the imitation of customs or fashions through sympathy or obedience, instruction or education, naïve or carefully considered imitation. (ibid, p. 38)

According to Tarde, imitations always involve variations and simultaneously bring about innovations in social structures and practices. 
Added to this are individual initiatives and rebellions against prevailing morals, customs, rules - interruptions or crossings of 'imitation streams' that are transferred and imitated from person to person, leading to social innovations.

"Researching the "many small inventions", according to Tarde, is a matter for a sociology which "has become a truly experimental science"' (Balke, 2009, p. 151). Social change must be viewed as a contingent phenomenon that resists any general (macro) theory. Because of the basic interdependence between social structures and social negotiation (Joas, 1992, p. 60), in every reproduced action there exists simultaneously the momentum of creation, change and transformation. The benefit of conceptualising a micro foundation of the social realm consists in decoding the recursive processes based on many small social inventions, ideas, initiatives and innovations as drivers of social change.

If social micro units are accorded constitutive importance for the dynamics of society, it becomes possible to describe social change not simply as a trend in the sense of a transition from one state at time $t$ to another at time $t_{1}$, but to see it as an independent non-deterministic reality. Thus, social innovation can be understood as a 'starting point for creating social dynamics behind technological innovations' (Geels, 2006, p. 6), that is, as change that arises as a result of constant changes by inventive and imitating actors (Tarde, 2009c, p. 67). With Tarde, social change can be traced back to the effects of small and micro units. Change is explained from the bottom up in current discourse on social transformation processes, as a fundamental prerequisite for substantial change (Paech, 2012). Its emergence from unintended and intentional deviations from the ideal of imitation provides the possibility of linking micro and macro perspectives (Gilgenmann, 2010, p. 7) - connecting a view of individuals in their society with a view of the society as a whole.

While the macro perspective looks at how social facts and constructs impact on social life, that is, it refers to the power of structures, institutions etc. to shape actions (see, for example, Hasse and Krücken, 2005, p. 17), the micro perspective on the social realm focuses on the 'law of their formation' (Tarde, 2009a, p. 101) and discovers how they emerge and transform, that is, it enables a micro foundation of social change. The key to analysis, therefore, lies in identifying social innovations that spread through society as a result of imitation to bring about social change: a 'process of change in the social structure of a society in its constitutive institutions, cultural patterns, associated social actions and conscious awareness' (Zapf, 2003, p. 427). These are non-teleological and highly contingent processes. 
Tarde devised and pursued an analytical agenda that made social innovation the starting point for understanding social conditions and how they change. Accordingly,

the real causes of change consist of a chain of certainly very numerous ideas, which however are different and discontinuous, yet they are connected together by even far more numerous acts of imitation, for which they serve as a model. (Tarde, 2009b, p. 26)

For Tarde, there was only one decisive factor driving the constitution of society: the mutual imitation of individuals, kept moving by innovations of others (Keller, 2009, p. 233).

Development and change are enabled by invention, by successful initiatives that are imitated, and hence become (social) innovations: 'Social transformations are explained by the individual initiatives which are imitated' (Tarde, 1902, p. 1; as quoted by Michaelides and Theologou, 2010, p. 363). These are the directing, determining and explanatory force, the 'key drivers of social transformation processes' (Moebius, 2009, p. 269).

\section{A new understanding of innovation and a new innovation policy?}

Based on Tarde's concept of innovation, key conclusions can be drawn with regard to a new understanding of innovation that contributes to its theoretical foundations and to the policy concepts associated with it.

\section{Social innovation as a driver of social change}

Social innovation is a central driver and element of social change. Hence, it is not surprising that it occupies a key position in debates concerned with how best to address major social challenges. It is important here to look at the findings of research on the genesis of technology and, in particular, at those approaches that tackle questions of transition management and sociotechnical system change (cf. Geels and Schot, 2007). Geels and Schot pursued a multi-level approach (MLP) by distinguishing three levels: niche innovations, the sociotechnical regime and the sociotechnical landscape. They understood 'transitions as outcomes of alignment between developments at multiple levels' or 'as changes from one sociotechnical regime to another' (ibid., p. 399). Starting from these basic assumptions, the authors developed a typology of transformation processes that differentiated between available 
resources (internal/external) and the degree of coordination. Whereas 'endogenous renewal' is performed by actors within an existing regime in the form of consensus-oriented and planned efforts as a response to perceived pressure using resources internal to the regime - the 'reorientation of trajectories' results from a shock. In contrast, an 'emergent transformation' results from uncoordinated pressure from outside of the system boundaries, while 'purposive transition' is initiated from outside the existing regime as an intended and coordinated transformation process (ibid., p. 401).

These considerations allow for a closer inspection of the relationship between social innovation and social change. Seen in the light of Tarde's approach, new practices of social action would, first, be discovered and invented at the micro level, in social niches. From there, they could be imitated and spread by particular actors or networks of actors, ${ }^{8}$ changing themselves in this process. Furthermore, new social practices can develop outside of the prevailing imitation streams. Together with changes in the sociotechnical landscape - that exert pressure on the predominant sociotechnical system (for example, through environmental changes such as climate change) - or systemic dysfunctions (financial crisis, unemployment, social inequality, etc.), these developments can result in the destabilisation of the system and open up windows of opportunity for creating and spreading out niche innovations leading to transformation and, ultimately, the institutionalisation of new social practices.

With regard to the need for a comprehensive transformation of the dominant economic growth model, Meadows et al. (1972, p. 173) pointed out 'that social innovation can no longer lag behind technological innovation'. Likewise, the directed, rapid and far-reaching transformation that is demanded by the notion of sustainable development explicitly addresses radical changes at the level of political governance and social practices that go far beyond technological innovations. Transformative social change here is no longer understood to be a largely uncontrolled outcome of gradual evolutionary developments (cf. Osterhammel, 2011) but as something that can, in principle, be shaped by society - 'by the actors and their innovations' (Schneidewind, 2013, p. 123). To rely on new technologies alone to achieve this is regarded as insufficient on account of the problem-shifting, secondary, consequences and rebound effects that may frequently accompany them. The necessary transformation - that is already emerging in many areas, yet at the same time is also comprehensively blocked in others - needs to be shaped by society and demands new concepts of welfare, diverse social 
innovation, and an as yet unattained level of international cooperation (cf. WGBU, 2011).

This makes it necessary to place the transformation of ideas and initiatives as an independent form of innovation at the centre of processes of social self-organisation and real-life experiments embedded in them, as well as imitation processes going beyond them, and, relating to this, at the centre of a 'truly experimental science' (Tarde, 2009a, p. 101).

\section{The importance of successful imitation to disseminate social innovation}

Tarde's approach can also be used to bring about an important shift in perspective. Rather than constantly producing new individual inventions, it seems more meaningful creatively to reconfigure the opportunities presented by existing inventions through social practice:

The qualities that in any age and in any land make a man superior are those which make him better able to understand the discoveries already made and exploit the inventions already devised. (Tarde, 2009b, p. 251)

In this context, the wealth of a nation, for Tarde, was rooted in its ability to 'use the knowledge of its time in a particular way' (ibid., p. 254). If, like Tarde, a situation is explained from the imitation practices of people, then the specific cultural frameworks need to be decoded.

At the same time, inventions can also be adopted from other cultural groups. Not only Tarde, but later Ogburn too, emphasised:

The inhabitants of a cultural group can also come into possession of inventions, without making inventions themselves, by importing them from other countries. In fact, most inventions found within a specific area are imported [...] (Ogburn, 1969, p. 62)

Ogburn also pointed to the Renaissance in Italy, which owed its creativity to the inflow of ideas from antiquity.

With the shift in perspective from inventions to social practices of imitation, the key question in the context of diffusion is how new social practices come into being from the imitation of social practices. The concept of imitation underpins an understanding of innovation that focuses on social practices. Practices of organisation, consumption, production and so forth become the central object of Tarde's conception of imitation. This includes the production and consumption of 
technological artefacts. The spread of social ideas or initiatives through imitation tends to combine with other inventions to form increasingly complex and more widely acting social innovations. Imitation always involves variation and, to this extent, imitations constantly bring about innovations in social structures and constructs.

\section{The diffusion of social innovation}

With regard to the debate surrounding the importance of social innovation (cf. Franz, Hochgerner and Howaldt, 2012), the question of the possibilities for its (fast and sustained) spread or diffusion has become important. Rogers, who has decisively influenced research on the diffusion of innovations, also regarded Tarde as a source of inspiration for his own ideas and believed him to have been far ahead of his time (cf. Rogers, 2003, p. 41). Rogers' approach to diffusion, which is still dominant in business contexts, exhibited a series of links to Tarde that can assist in understanding the mechanisms by which social innovation can spread. At the same time, however, Rogers' reinterpretation of Tarde has contributed to a problematic narrowing of diffusion research. His references to Tarde are by no means 'slightly different concepts' (Rogers, 2003 , p. 41), rather, they are a serious change of perspective. Whereas Tarde's sociology is interested in the genesis of the new as social practice, Rogers took innovation (as rational problem-solving produced by science and technology) for granted and focused on its transfer into different areas of application. Thus, Rogers severed the direct connection between invention and innovation - through which an invention becomes an innovation - and reduced the creative process of imitation to its adaptive function. According to Rogers' definition, the innovation precedes the diffusion process. Diffusion refers to the acceptance and adoption of the innovation by the relevant individuals - namely, the innovation gains acceptance instead of being produced.

The associated diffusion research asks, with regard to the intended target groups, how the innovation can be substantively modified and prepared for information and communication purposes, so that the adoption rate can be increased and/or accelerated. It attempts to develop 'push strategies' aimed at speeding up the introduction of solutions into society (outside-in processes). Diffusion research is highly affected by a pro-innovation bias. It is guided by the conviction that the innovation is effective, with the assumption that the main problem is how to convince various target groups to adopt it. Diffusion research, therefore, generates an asymmetrical communication relationship between the developers and the users of problem solutions or innovations. Society 
itself - as the original source of innovation and creativity - is a blind spot in diffusion research. On the other hand, that which Rogers defines as the diffusion of an idea, technology and so on would be described in Tarde's terms as a process which initiates new acts of imitation and triggers cultural learning processes, while interrupting existing imitation streams and advancing social change. Inventions open up new opportunities, expose problems and shortcomings in established practices, initiate processes of learning and reflection, and ultimately enable new social practices to emerge. To this extent, for any invention, it is necessary to enquire about its potential to trigger such imitation and learning processes and, hence, generate new social practices. Only through the development of new social practices or changes to existing practices do their effects unfurl and inventions become innovations and, hence, social facts. In reality, therefore, the process of diffusion is a process centred on changing patterns of behaviour that sets social learning processes in motion that are triggered by new inventions.

The internal logic of these processes of imitation and social learning, that Tarde made the focus of his attention, determine the innovation process. The unpredictable dynamics of the self-organised interaction of heterogeneous actors dealing in various ways with innovations requires 'more realistic assumptions about decision-making processes' (Schröder et al., 2011, p. 28) and an approach that ultimately inverts Rogers' perspective. Whereas traditional diffusion research offers ex-post explanations of how individual innovations have ended up in social practice, the goal here is to develop approaches to understanding the genesis of innovations from the broad range of social practice. This focuses on the extent to which they are concerned not so much with the transfer and modification of isolated singular innovation offerings but, rather, with multiple innovation streams, fed by an evolutionary interplay of invention and imitation: the 'cycle of interlinked and recurring (repeating with variations) actions' (Tarde, 2009a, p. 73).

\section{The wisdom of the crowds and new forms of governance}

Tarde's proposition that any invention is embedded in a dense network of imitation streams shows that social innovations are, first and foremost, ensemble performances, requiring interaction between many actors. Above all, they need the 'wisdom of crowds'. As 'open' innovation - meaning the engagement of users, citizens and consumers in the innovation process - is a key characteristic of the new innovation paradigm (cf. Howaldt and Kopp, 2012, p. 45), there is also greater experimentation in innovation processes both in the world of scientific 
laboratories and in society (Krohn, 2005). Social innovators challenge established rules, routines, pathways and models in politics, business and society - such as the economisation of all areas of life and an inevitable link between prosperity and growth (Leggewie and Welzer, 2009; Jackson, 2012; WBGU, 2011) - and call them into question. In doing so, they lead the way to changed, alternative social practices and lifestyles that are the basis and relevant drivers of transformative social change (cf. for example, Jonker, 2012). The perspective of a conception of social innovation founded in social theory, therefore, focuses on the interfaces between the self-referencing social sectors of government, business and civil society - that are distinct, and largely shielded, from each other and on their respective rationales of action and regulatory mechanisms, their limited problem-solving capacities, and other associated problems. Regarding the governance question of how these interfaces could be reconfigured, established patterns of control and coordination may be added to, expanded and remoulded via processes such as selforganisation, inter-sectoral cooperation, networks and new forms of knowledge production. The associated processes of 'cross-sector fertilisation' (Phills, Deiglmeier and Miller, 2008, p. 40 ff.) and convergence of sectors (Austin et al., 2007) increasingly enable a kind of blended value creation (Emerson, 2003) and, in some cases, promote a 'moralisation of markets' (Stehr, 2007). Such cross-sector fertilisations and convergences require and enable far-reaching social innovations that set in motion and spur the blurring of sector boundaries. In view of the complex interdependencies between the different social sectors, system levels and levels of action, social innovations are necessarily separate from, and in addition to, technological and economic innovations 'in order to reach systemic synergies, productivity growth, increasing returns and steadily growing incomes' (Hämäläinen and Heiskala, 2007).

Social practices are basic operations whose execution and repetition drives stability and instability, order as well as the emergence of something new. Changing social practices usually involves a drawnout, contingent and self-organised process that, as Tarde pointed out, is subject to its own 'laws' - the laws of imitation. Previous policy attempts to manage the implementation of new practices (for example, in organisations, in mobility and in health systems) have generally proven to be difficult. A comprehensive innovation policy agenda would, in addition to supporting new technologies, also focus on social innovation by enabling actors 'to suspend established routines and patterns, as only then can new ideas and behaviours thrive' (Adolf, 2012 , p. 40). Such an agenda would foster the necessary freedom to do 
this and the opportunities 'to share objectified and personal (implicit) knowledge' (ibid., p. 41).

One of the key tasks in this regard is a redefinition of the relationships between policy and the 'new power of the citizenry' (Marg et al., 2013), civil society engagement, the many and diverse initiatives and movements 'for the transformation of our type of industrial society' (Welzer, 2013, p. 187):

A central element here is to enable citizens [in the sense of empowerment - authors' note] to share in responsibility for the future, which should not be equated with personal responsibility in the neoliberal sense. (Rückert-John, 2013, p. 291)

This demands a change in perspective from a logic of transfer to a logic of transformation. The question is not about how to introduce solutions into society, but rather how to transform existing solutions to better arrangements. The means of doing this is multi-stakeholder dialogue that enables actors to articulate ideal outcomes and identify actions for their realisation and implementation.

\section{Conclusion}

As shown above, the emerging concept of social innovation suffers as a result of its poor social theoretical foundations with the consequence that there is a lack of clarity, especially concerning the relationship between social innovation and transformative social change. By defining social innovation as 'a new combination or configuration of practices', a more effective approach can be found in social practice theories because they focus on social practices as the central theoretical and analytical category and last unit of sociality. It has been suggested here that an important point of reference is Tarde's micro-sociological and poststructuralist approach. For Tarde, in the social everything occurs through invention and imitation (cf. Tarde, 2009b, p. 27). Tarde's concept of imitation provides important insights for analysing how practices are created and institutionalised. Tarde devised and pursued an analytical agenda that made social innovation the starting point for understanding social conditions and how they change. As such, a theoretical foundation of social innovation can fundamentally benefit from Tarde's social theory. Taking his micro sociological approach as a starting point, key implications can be outlined for a theoretically grounded understanding of social innovation and for an innovation policy that builds upon this. 
By reference to Tarde's social theory it is possible to develop a robust and comprehensive concept of social innovation and its relationship to social change. It also allows for the analysis of the relationship between social and technological innovation and a better understanding of the most appropriate conditions for introducing, implementing, diffusing and establishing social innovation as a new social practice.

Starting from the interdependent relations between the elements of social practices, social innovations can be seen as central drivers and elements of social change. The internal logic of these processes of imitation and social learning, that is the focus of Tarde's attention, determines the innovation process. Whereas traditional diffusion research offers ex-post explanations of how individual innovations have ended up in social practice, the goal here is to develop approaches to understanding the genesis of innovations from the broad range of social practice with special attention paid to multiple innovation streams, fed by an evolutionary interplay of invention and imitation: the 'cycle of interlinked and recurring (repeating with variations) actions' (Tarde, 2009c, p. 73). If Tarde's perspective is followed in pointing to the social embeddedness of any invention in a dense network of imitation streams, then social innovations are first and foremost ensemble performances, requiring the interaction of many actors and, therefore, cross-sector analyses of the dynamics of social practices and the corresponding governance of transition in practice.

If the question of the relationship between social innovation and social change is to become a core issue for public and policy discussion, then recourse to Tarde highlights a wider set of issues within a nondeterministic explanation of social change as a key element of social transformation processes. Because Tarde placed the practices of imitation at the heart of his theory of social development, reference to the associated micro foundations of social phenomena can provide useful input into an integrative theory of innovation. As a robust scientific conceptualisation of active social life (cf. Toews, 2013, p. 401), it enables an analysis of how social phenomena, conditions and constructs come into being and how they change.

A sociologically grounded innovation theory can examine many and varied imitation streams and help decode their logics and laws. From this perspective, the focus is always on social practices, since it is only via social practices that diverse inventions make their way into society and, thus, become the object of acts of imitation. Social practice is a central component of a theory of transformative social change, in which a wide variety of everyday inventions constitutes stimuli and 
incentives for reflecting on - and possibly changing - social practices. It is only when these stimuli are absorbed, leading to changes in existing social practices that spread through society and construct social cohesion via acts of imitation, that they drive social transformation. Thus, new perspectives open up on an understanding of innovation that fully captures the diversity of innovations in society.

The great challenge for contemporary innovation policy lies in exploiting these possibilities. Nearly seventy years ago, in his 1945 report to President Roosevelt, Vannevar Bush directed the pioneering spirit towards exploring the 'endless frontiers' of natural science research, hoping that this would promote social welfare (Bush, 1945).

Today, there is a need for a fundamental broadening of perspective. First, challenges are present on a global scale and overcoming them requires a global perspective. Second, the major challenges are in the social sphere. The Vienna Declaration (2011) stated:

The most urgent and important innovations in the 21st century will take place in the social field. This opens up the necessity as well as

possibilities for Social Sciences and Humanities to find new roles and relevance by generating knowledge applicable to new dynamics and structures of contemporary and future societies.

In the middle of the last century, conditions were created - based on systematic innovation policy - that allowed exploration of the possibilities of the natural sciences to make them usable for society. In a similar way, there is now a need for a pioneering spirit in the search for new social practices that enable a secure future and allow people to live 'a richer and more fulfilled human life' (Rorty, 2008, p. 191).

The observations set out in this chapter make it clear that increased attention to social innovation is necessary to develop the potential for new social practices beyond the current, dominant, economic growth model. To this extent, a new model for innovation policy is required that directs its focus from technologies onto social innovations and systemic solutions and onto a corresponding empowerment of actors, thus transforming it into a comprehensive social policy.

\section{Notes}

1. The term relates to the Schumpeterian terminology, defining innovations as 'new combinations of production factors' (Howaldt and Schwarz, 2010; Hochgerner, 2012).

2. First mentioned by anthropologist Sherry B. Ortner (Ortner, 1984). 
3. Important exceptions are, for example, Mulgan, 2012, and Hochgerner, 2009.

4. It centres on the question of whether social innovations are a prerequisite for a phenomenon that is concomitant with, or a consequence of, technological innovations (cf. Zapf, 1989; Gillwald, 2000, p. 38 ff.; Freeman, 1996; MeyerKrahmer, 1998).

5. Duncan also highlighted this clarification in his introduction to Ogburn's works: 'It is wrong to characterize Ogburn's theory of social change as a "cultural lag theory". He did not regard the cultural lag theory as a "fundamental element of the theory of social evolution"' (Duncan, 1969, p. 21). He goes on to state: 'Ogburn makes it quite clear that one should in no way assume that all lags are initiated by technological inventions, to which social forms must subsequently sooner or later adapt. This statement results only from a generalization of empirical findings for a particular historical period, and even for this period it is not said to be valid without exception' (ibid., p. 22).

6. For many years, this one-sided technology orientation has found expression in an innovation policy that concentrates on supporting leading-edge technologies. The many reasons for this trend are founded, for example, in the various models of economic growth theory (cf. Hirsch-Kreinsen, 2010).

7. A recent article by Palmås (2012) explores the implications of Tarde's theories for the study of social entrepreneurship.

8. 'Niche innovations are carried and developed by small networks of dedicated actors, often outside the fringe actors' (Geels and Schot, 2007, p. 400).

9. '[...] Without scientific progress no amount of achievement in other directions can insure our health, prosperity, and security as a nation in the modern world' (Bush, 1945, p. 11).

'The Government should accept new responsibilities for promoting the flow of new scientific knowledge and the development of scientific talent in our youth. These responsibilities are the proper concern of the Government, for they vitally affect our health, our jobs, and our national security. It is in keeping also with basic United States policy that the Government should foster the opening of new frontiers and this is the modern way to do it. For many years the Government has wisely supported research in the agricultural colleges and the benefits have been great. The time has come when such support should be extended to other fields' (Bush, 1945, p. 8).

\section{References}

Adolf, M. (2012) 'Die Kultur der Innovation. Eine Herausforderung des Innovationsbegriffs als Form gesellschaftlichen Wissens', in Hilty, R.M., Jaeger, T. and Lamping, M. (eds), Herausforderung Innovation. Eine interdisziplinäre Debatte. Berlin, Heidelberg: Springer.

Austin, J.E., Gutierrez, R., Ogliastri, E. and Reficco, E. (2007) 'Capitalizing on Convergence', Stanford Social Innovation Review, 5 (4): 24-31.

Balke, F. (2009) 'Eine frühe Soziologie der Differenz: Gabriel Tarde', in Borch, C. and Stäheli, U. (eds), Soziologie der Nachahmung und des Begehrens. Materialien zu Gabriel Tarde. Frankfurt a.M.: Suhrkamp.

BEPA (2010) Empowering People, Driving Change. Social Innovation in the European Union. Brussels: Bureau of European Policy Advisers and European Commission. 
Bijker, W.E., Hughes, T.P. and Pinch, T.J. (eds) (1987) The Social Construction of Technological Systems. New Directions in the Sociology and History of Technology. Cambridge, MA: MIT Press.

Brand, K.W. (2011) 'Umweltsoziologie und der praxistheoretische Zugang', in Gross, M. (ed.), Handbuch Umweltsoziologie. Wiesbaden: VS-Verlag für Sozialwissenschaften.

Bush, V. (1945) Science, the Endless Frontier. A Report to the President by Vannevar Bush. Washington, DC: Director of the Office of Scientific Research and Development.

Cajaiba-Santana, G. (2014) 'Social Innovation: Moving the Field Forward. A Conceptual Framework', Technological Forecasting \& Social Change, 82: 42-51. Cooperrider, D.L. and Pasmore, W.A. (1991) 'Global Social Change: A New Agenda for Social Science?’ Human Relations, 44: 1037-55.

Crozier, M. and Friedberg, E. (1993) Die Zwänge kollektiven Handelns - Über Macht und Organisation. Frankfurt a.M.: Hain.

Duncan, O.D. (1969) 'Einleitung', in Ogburn, W.F., Kultur und Sozialer Wandel. Ausgewählte Schriften. Herausgegeben und eingeleitet von Otis Dudley Duncan. Soziologische Texte, 56. Neuwied, Berlin: Luchterhand.

Emerson, J. (2003) 'The Blended Value Proposition. Integrating Social and Financial Returns', California Management Review, 45 (4): 35-51.

European Commission (2013) Social innovation research in the European Union. Approaches, findings and future directions. Policy Review. Brussels: European Commission.

FORA (2010) New Nature of Innovation. Report to the OECD. Copenhagen.

Franz, H.W., Hochgerner, J. and Howaldt, J. (2012) Challenge Social Innovation. Potentials for Business, Social Entrepreneurship, Welfare and Civil Society. Berlin, New York: Springer.

Freeman, C. (1996) 'The Greening of Technology and Models of Innovation', Technological Forecasting and Social Change, 53 (1): 27-39.

Freeman, C. (1974) The Economics of Industrial Innovation. Harmondsworth: Penguin.

Geels, F.W. (2006) 'Multi-level Perspective on System Innovation', in Olsthoorn, A. and Wieczorek, A.J. (eds), Understanding Industrial Transformation: Views from Different Disciplines. Dordrecht: Springer.

Geels, F. W. and Schot, J. (2007) 'Typology of sociotechnical transition pathways', Research Policy, 36(3):399-417.

Gilgenmann, K. (2010) 'Gabriel Tarde oder die Erfindung und Nachahmung eines Klassikers', Soziologische Revue, 33 (3): 261-86.

Gillwald, K. (2000) Konzepte sozialer Innovation. WZB paper: Querschnittsgruppe Arbeit und Ökologie. Berlin.

Gross, M., Hoffmann-Riem, H. and Krohn, W. (2005) Realexperimente. Ökologische Gestaltungsprozesse in der Wissensgesellschaft. Bielefeld: transcript.

Hämäläinen, T.J. and Heiskala, R. (2007) Social Innovations, Institutional Change and Economic Performance. Making Sense of Structural Adjustment Processes in Industrial Sectors, Regions and Societies. Cheltenham, Northampton: Edward Elgar.

Hargraves, T., Haxeltine, A., Longhurst, N. and Seyfang, G. (2011) Sustainability transitions from the bottom up: Civil society, the multi-level perspective and practice theory, CSERGE Working Paper 2011-01. Available at: http://www. cserge.ac.uk/publications/cserge-working-paper/2011-01-sustainability-transi tions-bottom-civil-society-multi-level [Accessed 5 November 2014.] 
Hasse, R. and Krücken, G. (2005) Neo-Institutionalismus. Bielefeld: transcript.

Hirsch-Kreinsen, H. (2010) 'Die "Hightech-Obsession" der Innovationspolitik', in Howaldt, J. and Jacobsen, H. (eds), Soziale Innovation. Auf dem Weg zu einem postindustriellen Innovationsparadigma. Wiesbaden: VS.

Hochgerner, H.-W. (2012) 'New Combinations of Social Practices in the Knowledge Society', in Franz, H.-W., Hochgerner, J. and Howaldt, J. (eds), Challenge Social Innovation. Potentials for Business, Social Entrepreneurship, Welfare and Civil Society. Berlin, New York: Springer.

Hochgerner, J. (2009) 'Innovation Processes in the Dynamics of Social Change', in Loudin, J. and Schuch, K. (eds), Innovation Cultures. Challenge and Learning Strategy. Prague: Filosofia.

Howaldt, J. and Kopp, R. (2012) 'Shaping Social Innovation by Social Research', in Franz, H. W., Hochgerner, J. and Howaldt, J. (eds), Challenge Social Innovation. Potentials for Business, Social Entrepreneurship, Welfare and Civil Society. Berlin, New York: Springer.

Howaldt, J. and Schwarz, M. (2010) 'Soziale Innovation' im Fokus. Skizze eines gesellschaftstheoretisch inspirierten Forschungskonzepts. Bielefeld: transcript.

Howaldt, J., Kopp, R. and Schwarz, M. (2014) Zur Theorie sozialer Innovationen. Tardes vernachlässigter Beitrag zur Entwicklung einer soziologischen Innovationstheorie. Weinheim und Basel: Beltz Juventa.Jackson, T. (2012) Wohlstand ohne Wachstum. Leben und Wirtschaften in einer endlichen Welt. Bonn: Bundeszentrale für Politische Bildung.

Joas, H. (1992) Die Kreativität des Handelns. Frankfurt a.M.: Suhrkamp.

Jonker, J. (2012) Sustainable Thinking and Acting. An Inspirational Book for Shaping Our Common Future. Deventer: Kluver.

Keller, F. (2009) 'Das endgültige soziale Rom. Tarde, Saussure und darüber hinaus', in Borch, C. and Stäheli, U. (eds), Soziologie der Nachahmung und des Begehrens. Materialien zu Gabriel Tarde. Frankfurt a.M.: Suhrkamp.

Krohn, W. (2005) 'Einleitung', in Gross, M., Hoffmann-Riem, H. and Krohn, W. (eds), Realexperimente. Ökologische Gestaltungsprozesse in der Wissensgesellschaft. Bielefeld: transcript.

Latour, B. and Lépinay V. (2010) Die Ökonomie als Wissenschaft der leidenschaftlichen Interessen. Eine Einführung in die ökonomische Anthropologie Gabriel Tardes. Frankfurt a. M.: Suhrkamp.

Leggewie, C. and Welzer, H. (2009) Das Ende der Welt, wie wir sie kannten. Klima, Zukunft und die Chancen der Demokratie. Frankfurt a.M.: Fischer.

MacKenzie, D. and Wajcman, J. (eds) (1985) The Social Shaping of Technology. London: Open University Press.

Marchart, O. (2013) Das unmögliche Objekt. Eine postfundamentalistische Theorie der Gesellschaft. Berlin: Suhrkamp Verlag

Marg, S., Geiges, L., Butzlaff, F. and Walter, F. (2013) Die neue Macht der Bürger. Was motiviert Protestbewegungen? BP-Gesellschaftsstudie. Reinbek: Rowohlt. Meadows, D.L., Meadows, D.H. and Zahn, E. (1972) Die Grenzen des Wachstums. Bericht des Club of Rome zur Lage der Menschheit. Stuttgart: Deutsche VerlagsAnstalt.

Meyer-Krahmer, F. (ed.) (1998) Innovation and Sustainable Development. Lessons for Innovation Policies. Heidelberg: Physica.

Michaelides, P.G. and Theologou, K. (2010) 'Tarde's Influence on Schumpeter: Technology and Social Evolution', International Journal of Social Economics, 37 (5): 361-73. 
Moebius, S. (2009) 'Imitation, differentielle Wiederholung und Iterabilität. Über eine Affinität zwischen Poststrukturalistischen Sozialwissenschaften und den "sozialen Gesetzen" von Gabriel Tarde', in Borch, C. and Stäheli, U. (eds), Soziologie der Nachahmung und des Begehrens. Materialien zu Gabriel Tarde. Frankfurt a.M.: Suhrkamp.

Moore, M.-L. and Westley, F. (2011) 'Surmountable Chasms: Networks and Social Innovation for Resilient Systems', Ecology and Society, 16 (1): 5.

Moulaert, F., MacCallum, D., Mehmood, A. and Hamdouch, A. (eds) (2013) The International Handbook on Social innovation. Collective Action, Social Learning and Transdisciplinary Research. Cheltenham: Edward Elgar.

Mulgan, G. (2012) 'Social Innovation Theories: Can Theory Catch Up with Practice?' in Franz, H.W., Hochgerner, J. and Howaldt, J. (eds), Challenge Social Innovation. Potentials for Business, Social Entrepreneurship, Welfare and Civil Society. Berlin, New York: Springer.

Mulgan, G., Tucker, S., Ali, R. and Sanders, B. (2007) Social Innovation: What It Is, Why It Matters and How It Can Be Accelerated. Oxford: Skoll Centre for Social Entrepreneurship.

Ogburn, W. F. (1969) Kultur und sozialer Wandel. Ausgewählte Schriften. Herausgegeben und eingeleitet von Otis Dudley Duncan. Soziologische Texte, 56. Neuwied, Berlin: Luchterhand.

Ogburn, W. F. (1937) Technological Trends and National Policy. Including the Social Implications of New Inventions. Washington, DC: United States Government Printing Office.

OECD (1997) Oslo Manual: Proposed Guidelines for Collecting and Interpreting Technological Innovation Data. Paris: Organisation for Economic Co-operation and Development.

Ortner, S. B. (1984) 'Theory in Anthropology since the Sixties', Comparative Studies in Society and History, 26(1): 126-66.

Osrecki, F. (2011) Die Diagnosegesellschaft. Zeitdiagnostik zwischen Soziologie und medialer Popularität. Bielefeld: transcript.

Osterhammel, J. (2011) Die Verwandlung der Welt. Eine Geschichte des 19. Jahrhunderts. Munich: Beck.

Paech, N. (2012) Befreiung vom Überfluss. Aufdem Weg in die Postwachstumsökonomie. Munich: oekom.

Palmås, K. (2012) 'Re-assessing Schumperian Assumptions Regarding Entrepreneurship and the Social', Social Enterprise Journal, 8 (2): 141-55.

Phills Jr., J., Deiglmeier, K. and Miller, D. (2008) 'Rediscovering Social Innovation', Stanford Social Innovation Review, 6 (3): 33-43.

Powell, W.W. and Grodal, S. (2005) 'Networks of Innovators', in Fagerberg, J., Mowery, D. C. and Nelson, R.R. (eds), The Oxford Handbook of Innovation. New York: Oxford University Press.

Rammert, W. (2010) 'Die Innovationen in der Gesellschaft', in Howaldt, J. and Jacobsen, H. (eds), Soziale Innovation. Auf dem Weg zu einem postindustriellen Innovationsparadigma. Wiesbaden: VS.

Reckwitz, A. (2003) 'Grundelemente einer Theorie sozialer Praktiken. Eine sozialtheoretische Perspektive', Zeitschrift für Soziologie, 32 (4): 282-300.

Rogers, E. M. (2003) Diffusion of Innovations. New York: Free Press.

Rorty, R. (2008) Philosophie als Kulturpolitik. Frankfurt a.M.: Suhrkamp.

Rückert-John, J. (2013) ‘Die Nachhaltigkeit der Debatte um soziale Innovationen Innovationsschub für den nachhaltigen Wandel', in Rückert-John, J. (ed.), Soziale Innovationen und Nachhaltigkeit. Wiesbaden: Springer VS. 
Rüede, D. and Lurtz, K. (2012) Mapping the various meanings of social innovation: Towards a differentiated understanding of an emerging concept. EBS Business School Research Paper Series 12-03, Oestrich-Winkel.

Schatzki, T. R., Knorr-Cetina, K. and Savigny, E. von (eds) (2001) The Practice Turn in Contemporary Theory. London, New York: Routledge.

Schneidewind, U. (2013) 'Wandel verstehen - Auf dem Weg zu einer "Transformative Literacy"', in Welzer, H. and Wiegandt, K. (eds), Wege aus der Wachstumsgesellschaft. Frankfurt a.M.: Fischer Taschenbuch.

Schröder, T., Huck, J. and Haan, G. de (2011) Transfer sozialer Innovationen. Eine zukunftsorientierte Fallstudie zur nachhaltigen Siedlungsentwicklung. Wiesbaden: VS.

Schumpeter, J.A. (1964) Theorie der wirtschaftlichen Entwicklung. Berlin: Duncker \& Humblot.

Shove, E. (2003) 'Converging Conventions of Comfort, Cleanliness and Convenience', Journal of Consumer Policy, 26: 395-418.

Shove, E., Pantzar, M. and Watson, M. (2012) The Dynamics of Social Practice. Everyday Life and How It Changes. London: Sage.

Stehr, N. (2007) Die Moralisierung der Märkte. Eine Gesellschaftstheorie. Frankfurt a.M.: Suhrkamp.

Tarde, G. (2009a) Die sozialen Gesetze. Skizze einer Soziologie (1899). Marburg: Metropolis.

Tarde, G. (2009b) Die Gesetze der Nachahmung. Frankfurt a.M.: Suhrkamp.

Tarde, G. (2009c). Monadologie und Soziologie. Frankfurt a.M.: Suhrkamp.

Toews, D. (2013) 'Tarde's Sociology of Difference: Its Classical Roots and Contemporary Meanings', Journal of Classical Sociology, 13 (3): 393-401.

Vienna Declaration (2011) The Most Relevant Topics in Social Innovation Research. Concluding resolution provided by the conference 'Challenge Social Innovation. Innovating Innovation by Research - 100 Years after Schumpeter'. Available at: http://www.socialinnovation2011.eu/ [Accessed 5 November 2014.]

Vobruba, G. (2013). 'Soziologie und Kritik', Soziologie, 42 (2): 147-68.

Warde, A. (2005) 'Consumption and Theory of Practice', Journal of Consumer Culture, 5 (2): 131-53.

WBGU (Wissenschaftlicher Beirat der Bundesregierung) (2011) Globale Umweltveränderungen 2011: Welt im Wandel. Zusammenfassung für Entscheidungsträger. Gesellschaftsvertrag für eine Grosse Transformation. Berlin.

Welzer, H. (2013) Selbst denken. Eine Anleitung zum Widerstand. Frankfurt a.M.: Fischer.

Weymann, A. (1998) Sozialer Wandel: Theorien zur Dynamik der modernen Gesellschaft. Weinheim, Munich: Juventa.

Williams, R. and Sörensen, K. (2002) Social Shaping, Guiding Policy. Concepts, Spaces, and Tools. Edinburgh: Edward Elgar.

Zapf, W. (2003) 'Sozialer Wandel', in Schäfers, B. (ed.), Grundbegriffe der Soziologie. Opladen: Leske Budrich.

Zapf, W. (1989) 'Über soziale Innovationen', Soziale Welt, 40 (1/2): 170-83.

Except where otherwise noted, this work is licensed under a Creative Commons Attribution 3.0 Unported License. To view a copy of this license, visit http://creativecommons.org/licenses/by/3.0/ 